\title{
PROGRAM FOR IMPROVING AUTONOMY AND SCIENTIFIC RESEARCH IN REMOTE EDUCATION
}

\author{
PROGRAMA DE MELHORIA DA AUTONOMIA E PESQUISA CIENTÍFICA NA \\ EDUCAÇÃO A DISTÂNCIA
}

\author{
PROGRAMA DE MEJORA DE LA AUTONOMÍA Y LA INVESTIGACIÓN CIENTÍFICA \\ EN LA ENSEÑANZA A DISTANCIA
}

\author{
Juana VENEGAS-CLAROS ${ }^{1}$ \\ Aracelli GONZALES-SÁNCHEZ ${ }^{2}$ \\ Luis ALEX-VALENZUELA ${ }^{3}$ \\ Joel VISURRAGA-AGÜERO ${ }^{4}$ \\ Carlos Augusto LUY-MONTEJO ${ }^{5}$
}

\begin{abstract}
Students in Regular Basic Education have shown some difficulties in developing autonomy during their learning sessions; however, this situation increased when remote education was implemented, due to mandatory confinement, caused by the emergence of Covid 19 , an alternative had to be sought, which allowed solutions to this situation to be provided. It was formulated as a study objective to implement a program for improving autonomy and scientific research in remote education. The method used was a quantitative approach, with experimental design, a population of 84 students from the I. E. Celso Lino Ricaldi was used, the program was applied in ten sessions, resulting after its implementation, in the post test, that $35.71 \%$ of the control group and $67.86 \%$ of the experimental group achieved the desired level. This data led to the conclusion that the program implemented has positive effects on the autonomous learning and scientific research of the chosen educational institution.
\end{abstract}

KEYWORDS: Autonomy. Science. Distance education. Research and program.

RESUMO: Os alunos do Ensino Básico Regular têm demonstrado algumas dificuldades em desenvolver autonomia durante as suas sessões de aprendizagem; no entanto, esta situação agravou-se com a implementação do ensino a distância, devido ao confinamento obrigatório, ocasionado pelo surgimento da Covid 19, devendo ser procurada uma alternativa que permitisse encontrar soluções para esta situação. Foi formulado como objeto de estudo a implantação de um Programa de Melhoria da Autonomia e da Pesquisa Científica em Educação a Distância. O método utilizado foi uma abordagem quantitativa, com delineamento

\footnotetext{
${ }^{1}$ University César Vallejo (UCV), Trujillo - Peru. Master's in education. ORCID: https://orcid.org/0000-00031068-3864. E-mail: jvenegas696@gmail.com

${ }^{2}$ University César Vallejo (UCV), Trujillo - Peru. Doctorate in Education. ORCID: https://orcid.org/0000-00030028-9177. E-mail: aracelligs@ @otmail.com

3 University César Vallejo (UCV), Trujillo - Peru. RENACYT qualified researcher. ORCID: https://orcid.org/0000-0002-8743-4092. E-mail: lvalenzuelafer@ucvvirtual.edu.pe

${ }^{4}$ Private University Norbert Wiener (UWIENER), La Victoria - Peru. Doctor in Public Management and Governance. ORCID: https://orcid.org/0000-0002-0024-668X. E-mail: jmvisurraga@gmail.com

5 Technological University of Peru (UTP), Lima - Peru. RENACYT qualified researcher. ORCID: https://orcid.org/0000-0003-0824-7959. E-mail: fracarlitos@gmail.com
}

RPGE- Revista on line de Política e Gestão Educacional, Araraquara, v. 25, n. esp. 3, p. 1580-1588, set. $2021 . \quad$ e-ISSN:1519-9029 
experimental, foi utilizada uma população de 84 alunos do I. E. Celso Lino Ricaldi, o programa foi aplicado em dez sessões, resultando após sua implantação, no pós-teste, que $35,71 \%$ do controle grupo e 67,86\% do grupo experimental atingiram o nível desejado. Esses dados levaram à conclusão de que o programa implementado tem efeitos positivos na aprendizagem autônoma e na pesquisa científica da instituição de ensino escolhida.

PALAVRAS-CHAVE: Autonomia. Ciência. Educação a distância. Pesquisa e programa.

RESUMEN: Los estudiantes de la Educación Básica Regular han mostrado algunas dificultades para desarrollar la autonomía durante sus sesiones de aprendizaje; sin embargo, esta situación se incrementó cuando se implementó la educación a distancia, debido a la obligatoriedad del encierro, provocada por el surgimiento del Covid 19, se tuvo que buscar una alternativa que permitiera dar solución a esta situación. Se formuló como objetivo del estudio la implementación de un Programa de mejora de la autonomía y la investigación científica en la educación a distancia. El método utilizado fue un enfoque cuantitativo, con diseño experimental, se utilizó una población de 84 estudiantes de la I.E. Celso Lino Ricaldi, se aplicó un programa en diez sesiones, resultando después de su implementación, en el post test que el 35,71\% del grupo control y el 67,86\% del grupo experimental están en el nivel alcanzado. Estos datos permitieron concluir que el programa aplicado tiene efectos positivos en el aprendizaje autónomo y la investigación científica de la institución educativa elegida.

PALABRAS CLAVE: Autonomía. Ciencia. Educación a distancia. Investigación y programa.

\section{Introduction}

The problems that students have in using autonomy to build their learning experiences have been a concern of Regular Basic Education (RBE) teachers, questioning what should be the appropriate actions to improve their development at school. According to Gutierrez et al. (2018), when teachers have a leadership role, they demonstrate the positive effect they can exert from a psychological point of view, motivating them and inviting them to make commitments to students can improve autonomy.

It is important to contextualize what the literature offers about the concept of autonomy, Prison (2016) defined it as a process in which strategies, instruments and time allocation will be chosen in fusion with learning styles, Moreno and Martínez (2007) claim that it contributes to self-fulfillment. For Bedoya et al. (2013), is a capacity for self-regulation; Lobato Fraile (2006) argued that the student acquires commitments that give him a style where he obtains the ability to plan, execute and assess his expertise when learning, and Pérez de Cabrera (2013) argued that the student takes control to build their learning.

Given the normative aspect in Peru of the Curriculum of Basic Education - CNEB (PERU, 2016): autonomous learning empowers students to carry out the learning process, 
establishing an order and priority of actions to be performed, as well as examining their achievements and difficulties in the use of skills that allow them to set goals to learn, organize strategies to achieve this goal and performance. Therefore, the theoretical contributions allowed to propose a conception in this study, that autonomy is a capacity with which the student regulates, plans and processes the way he acquires learning experiences.

However, the difficulties in acquiring this ability, according to Medina and Nagamine (2019), were due to the way education has been taught in Peru since colonial times, giving greater importance to cognitive skills and memorization. On the other hand, MaldonadoSánchez et al. (2019) state that one of the students' difficulties in using autonomous learning is the technology that allows them to easily obtain information. Unlike Quispe (2018), they argue that self-learning influenced by access to technological resources is strengthened. Another aspect that weakens students' autonomy is the way they process information, this due to their learning strategies, Maldonado-Sánchez et al. (2019) specified that if the right level of autonomy is not achieved, learning would be low.

Secondary school students were chosen to apply the Program, because to work in this age group this must be done from the school, this degree of agreement or the CNEB, corresponding to the sixth cycle of secondary education in Peru, in which they should have already acquired skills and performance levels that will continue to increase throughout their school education (RAYNAUDO; PERALTA, 2017). It is important to work with students from an early age to achieve meaningful learning, interrelated with the space around them.

The fact presented by Dewey in 1910, for the first time going against the traditional concept, that for knowledge to exist it was necessary to accumulate information, students should be allowed attitudes and skills that would allow them to explore knowledge (HEEDY; URIBE, 2008). On the other hand, Flórez-Nisperuza and De La Ossa (2017) observed that research contributes moderately to the interpretation of scientific ideas. Uzcátegui and Betancurt (2013) state that France is a reference for many countries in promoting research in the field of Science; the authors also ensured that the research helps the student to build approaches to science and can express it orally and in writing.

In secondary education standardized assessments are applied, the results of which, for Peru, are not very encouraging, as pointed out by the Quality Measurement Office (QMO), even with a slight increase until 2019, what happens at the level of secondary education is an exposition of low performance, also seen in basic education, which reinforces the need to start formation to acquire autonomy with children, aiming to improve their learning experiences. 
According to the results of the last Student Assessment Census carried out in 2019, published by the Ministry of Education (Minedu) and by the Quality Measurement Unit in 2020, it is possible to infer that there are difficulties in the academic performance of Peruvian students in the areas of Science and Technology.

The Science and Technology area was chosen due to the competences prioritized by Minedu in the context of the health emergency to Covid 19, so that students could academically understand the effects of this pandemic. The Basic Education Curriculum (PERU, 2016) says that learning in this area can form ethical and responsible citizens, capable of developing critical thinking, based on the skills of scientific and technological thinking: also capable of obtaining scientific information with which they can build their concepts and make decisions.

This study was implemented in the context of the health emergency originated by Covid 19 , with distance education being researched by those who addressed the issue of implementing this form of teaching in primary schools, which forced countries around the world to impose it as a solution, allowing them to avoid further contagion, assumptions are being made about how this system should be promoted.

For Almodóvar-López et al. (2020), in this scenario, it is important to involve families in their children's learning, García-Ruiz (2020) argued that to improve access to communication to technology, it is important, in addition to knowing its usefulness for education, to consider distance education to be important. Díaz-Barriga-Arceo and Barrón-Tirado (2020) had a more critical view of this form of teaching, due to the lack of digital skills and the attempt to bring the traditional to this form of teaching, they showed that there should be a change what the authors called disruptive curricular innovation, in the way the classes were taught, the weaknesses in access to technology by students was another negative factor considered.

Crisol-Moya, Herrera-Nieve and Montes-Soldado (2020), carried out a bibliographical review of pre-pandemic virtual education, which allowed them to verify the weaknesses of access to digital media by students, but this form of teaching could become more inclusive according to the diversity of its participants. Finally, in this context of distance education (SIANES; SÁNCHEZ, 2020), virtual education, given the uncertainty of its applicability, also required states to issue regulations to improve their implementation.

Therefore, this study was considered important as a contribution to the academic community, as if there were already difficulties in developing autonomy in face-to-face teaching and acting in the area of Science and Technology that would enable scientific research, how could a Program be implemented to improve scientific investigation during distance 
learning? Inferring that teenagers cannot be underestimated in the acquisition of skills, as long as teachers guide them properly.

\section{Methodology}

The investigation focused on the quantitative aspect; it was also considered as an explanatory study. Also, the drawing is quasi-experimental, quasi-experimental drawings are only given in real experiments. On the other hand, Sousal (2007) states that this experimental design examines the relationship between cause and effect between independent and dependent variables.

The program was applied in ten sessions to 84 high school students from the I. E. Celso Lino Ricaldi; the objective was to create scientific research activities and training feedback indicators to develop autonomous learning strategies; each session considered competencies, capabilities, purpose, evidence of challenge and assessment; as well as the typical pedagogical processes of the session, metacognition, the means through which it is made available and the resources used for its conception.

Given the situation, several means of connectivity were used to enable the development of learning sessions with students, with the help of parents. Also, to assess the beginning and progress of students, two instruments on a Likert scale were also designed to collect data on the learning variable. It was the CETA questionnaire, adapted and structured into 30 items, applied in the pre-test and post-test.

\section{Results}

The results were prepared based on the processing information, which was obtained by an instrument distributed by the Google form, as the descriptive statistics are as follows: 
Table 1 - The achievement levels of students' autonomous learning in science and technology at I.E. Celso Lino Ricaldi

\begin{tabular}{ccccccc}
\hline & & Pre-control & Pre-experimental & Post-control & Post-Experimental & Total \\
\hline Process & $\mathrm{N}$ & 23 & 25 & 18 & 9 & 75 \\
& $\%$ & $82.14 \%$ & $89.29 \%$ & $64.29 \%$ & $32.14 \%$ & 77 \\
Final & $\mathrm{N}$ & 5 & & & & \\
& $\%$ & $17.86 \%$ & 10.71 & $35.71 \%$ & $67.86 \%$ & $33 \%$ \\
& & & & & & \\
& $\mathrm{~N}$ & 28 & 28 & 28 & 28 & 112 \\
& $\%$ & $100.0 \%$ & $100.0 \%$ & $100.0 \%$ & $100.0 \%$ & $100,0 \%$ \\
\hline
\end{tabular}

Source: Prepared by the authors

According to Table 1, we have the descriptive results by levels both in the beginning and in the process and reached at the end, detailed below in the pre-test, we have that $82.14 \%$ of the control group and $89.29 \%$ of the experimental group are at the process level in their learning autonomy; but after the implementation of the program's scientific research, the feedback from the students' training, it is observed that $35.71 \%$ of the control group and $67.86 \%$ of the experimental group are at a more advanced level at the end, which means that the program applied has positive effects on the autonomous learning of students in the ecology of I. E. Celso Lino Ricaldi.

\section{Discussion}

As for the data obtained, it is observed that the implementation of the program guaranteed encouraging data about autonomous learning and scientific investigation in science and technology at I.E. Celso Lino Ricaldi. From the moment it is understood how the defined processes allow ordering ideas and actions (MALDOSWIM et al., 2018), as coding strategies are procedures that relate knowledge to prior knowledge and help to determine the level of autonomy. Canabal and Margalef (2017) also addressed the study that was carried out because autonomy brings new learning styles. González et al. (2020) applied their research on equal terms during the Covid 19 pandemic, obtaining encouraging data, in which this form of remote study contributed to the improvement of autonomy.

Taking scientific research in Science and Technology, Romero (2019), in the study he carried out, can demonstrate the significant development of projects for students to achieve scientific competence so that, to learn science, it is necessary to expand the research. Mollenedo (2019) determined that implementing research processes improves learning. These surveys confirmed that autonomy can be developed in students and this in turn contributes to the typical scientific research in Science and Technology. 


\section{Conclusions}

It is important to develop skills that strengthen scientific research in students, as the academic community is demonstrating the importance of science in strengthening student learning. In Peru, the school has been concerned with boosting the areas of Mathematics and Communication, as well as Science and Technology, as they are part of standardized international tests, but the Covid 19 pandemic demonstrated the need to provide a rational and scientific explanation about this disease, so this last area was prioritized, promoting health campaigns about this virus and its repercussions.

It is in this context that the use of strategies by teachers to get closer to students in the face of the uncertainty of distance education became complicated, fears that this study revealed as false, as effectively the promoted program and the application of the sessions allowed to obtain a satisfactory performance in the level of achievement of students, who demonstrated to increase their autonomy to carry out typical research in this new moment, both through classroom and distance learning.

\section{REFERENCES}

ALMODÓVAR-LÓPEZ, M. et al. La enseñanza remota no viene sin retos. Revista Electrónica Educare, v. 24, n. supl., p. 1-4, 2020. DOI: doi.org/10.15359/ree.24-s.15

BEDOYA, L. et al. La autonomía en la primera infancia desde el trabajo por proyectos. 2013. 106 f. Thesis (Doctorate) - Facultad de Educaciòn, Universidad Pontificia Bolivariana, Medellìn, 2013. Available: https://repository.upb. edu.co/handle/20.500.11912/1122. Access: 10 June 2020.

CANABAL, C.; MARGALEF, L. La retroalimentación: la clave para una evaluación orientada al aprendizaje. Profesorado, Granada (Spain), v. 21, n. 2, p. 150-170, 2017. Available: https://recyt.fecyt.es/index.php/profesorado/article/view/59454. Access: 10 June 2020.

CARRASCO, S. Metodologí de la investigación científica. Lima, Peru: Editorial San Marcos, 2019.

CRISOL-MOYA, E.; HERRERA-NIEVES, L.; MONTES-SOLDADO, R. Virtual education for all: Systematic review. Education in the Knowledge Society, v. 21, p. 1-13, 2020. DOI: doi.org/10.14201/eks.20327

DÍAZ-BARRIGA-ARCEO, F.; BARRÓN-TIRADO, M. C. Currículo y pandemia: Tiempo de crisis y oportunidad de disrupción. Revista Electrónica Educare, v. 24, n. supl., p. 1-5, 2020. DOI: doi.org/10.15359/ree.24-s.3 
FLÓREZ-NISPERUZA, E.; DE LA OSSA ALBIS, A. La indagación científica y la transmisión-recepción: una contrastación de modelos de enseñanza para el aprendizaje del concepto densidad. Revista Científica, v. 31, n. 1, p. 55-67, 2018. DOI:

doi.org/10.14483/23448350.12452

GARCÍA-RUIZ, R.; PÉREZ-ESCODA, A. Communication and education in a digital connected world. Presentation. Icono14, v. 18, n. 2, p. 1-15, 2020. DOI:

doi.org/10.7195/RI14.V18I2.1580

GONZÁLEZ, T. et al. Influence of COVID-19 confinement on students' performance in higher education. PLoS ONE, v. 15, n. 10, e0239490, 2020. DOI:

doi.org/10.1371/journal.pone.0239490

GUTIÉRREZ, M. et al. Autonomy support, psychological needs satisfaction, school engagement and academic success: A mediation model. Universitas Psychologica, v. 17, n. 5, 2018. DOI: doi.org/10.11144/Javeriana.upsy17-5.aspn

LOBATO FRAILE, C. El estudio y trabajo autónomo del estudiante. In: DE MIGUEL, M. (Dir.). Métodos y modalidades de enseñanza centradas en el desarrollo de competencias. Madrid, Spain: Alianza Universidad, 2006. Available:

https://www.uaem.mx/sites/default/files/facultad-de-medicina/descargas/aprendizajeautodirigido.pdf. access: 10 June 2020.

LÓPEZ, M. et al. La enseñanza remota no viene sin retos. Revista Electrónica Educare, v. 24, n. supl., p. 1-4, 2020. DOI: doi.org/10.15359/ree.24-s.15

MALDONADO-SÁNCHEZ, M. et al. Estrategias de aprendizaje para el desarrollo de la autonomía de los estudiantes de secundaria. Propósitos y Representaciones, v. 7, n. 2, p. 415-427, 2019. DOI: doi.org/10.20511/pyr2019.v7n2.290

MEDINA, D.; NAGAMINE, M. Estrategias de aprendizaje autónomo en la comprensión lectora de estudiantes de secundaria. Propós. represent., v. 7, n. 2, p. 134-146, 2019. ISSN 2307-7999. DOI: dx.doi.org/10.20511/pyr2019.v7n2.276

MORENO, R.; MARTÍNEZ, R. Aprendizaje autónomo. Desarrollo de una definición.

Revista Latina de Análisis de Comportamiento, v. 15, n. 1, 2007, p. 51- 62, 2007.

Universidad Veracruzana Veracruz, México. Available:

https://www.redalyc.org/pdf/2745/274520891004.pdf. Access: 10 June 2020.

PÉREZ DE CABRERA, L. El rol del docente en el aprendizaje autónomo: la perspectiva del estudiante y la relación con su rendimiento académico. Rev. Diálogos, n. 11, p. 45-62, 2013. Available: https://core.ac.uk/downl oad/pdf/47265063.pdf. Access: 10 June 2020.

PERU. Currículo Nacional de la Educación Básica - CNEB. Lima, Peru: Ministerio de Educación, 2016. Available: www.minedu.gob.pe. Access: 10 June 2020. 
QUISPE, J. Los recursos tecnológicos y su relación con el aprendizaje autónomo de los estudiantes de la escuela profesional de contabilidad, de la Universidad Católica los Ángeles de Chimbote, distrito Juliaca, año 2018. 2018. 111 f. Dissertation (Master's Degree in Education) - Universidad Católica los Angeles de Chimbote, Chimbote, Peru, 2018. Available: http://repositorio.uladech.edu.pe/handle/123456789/7528. Access: 10 June 2020.

RAYNAUDO, G.; PERALTA, O. Conceptual change: a glance from the theories of Piaget and Vygotsky. Liberabit: Revista Peruana de Psicología, v. 23, n. 1, p. 137-148, 2017. DOI: doi.org/10.24265/liberabit.2017.v23n1.10

SIANES, A.; SÁNCHEZ, E. E-learning en 15 días. Retos y renovaciones en la Educación Primaria y Secundaria de la República de Croacia durante la crisis del COVID-19. How has we Introduced distance Learning? Revista Española de Educación Comparada, v. 36, 2020.

SOUSAI, V. An overview of research designs relevant to nursing: Part 1: Quantitative research designs. Rev. Latino-Am. Enfermagem, v. 15, n. 3, 2007. DOI:

doi.org/10.1590/S0104-11692007000300022

UZCÁTEGUI, Y.; BETANCURT, C. La metodología indagatoria en la enseñanza de las ciencias: una revisión de su creciente implementación a nivel de Educación Básica y Media. Revista de Investigación, v. 37, n. 78, 2013. Available: http://ve.scielo.org/scielo.php?script=sci_arttext\&pid=S1010-29142013000100006. Access: 10 June 2020.

\section{How to reference this article}

VENEGAS-CLAROS， J.; GONZALES-SÁNCHEZ， A.; ALEX-VALENZUELA， L.; VISURRAGA-AGÜERO, J.; LUY-MONTEJO, C. A. Program for improving autonomy and scientific research in remote education. Revista on line de Política e Gestão Educacional, Araraquara, v. 25, n. esp. 3, p. 1580-1588, set. 2021. e-ISSN:1519-9029. DOI: https://doi.org/10.22633/rpge.v25iesp.3.15286

Submitted: 20/03/2021

Required revisions: 05/06/2021

Approved: $12 / 07 / 2021$

Published: 01/08/2021 